\title{
The effect of oral administration of monosodium glutamate on orofacial pain response and the estimated number of trigeminal ganglion sensory neurons of male Wistar rats
}

\author{
Amilia Ramadhani ${ }^{1 *}$, Zaenal Muttaqien Sofro ${ }^{2}$, and Ginus Partadiredja ${ }^{2}$ \\ ${ }^{1}$ Departement of Oral Biology, School of Dentistry, Medical Faculty, Jenderal Soedirman University, Purwokerto, Central Java, \\ Indonesia \\ ${ }^{2}$ Departement of Physiology, Faculty of Medicine, Universitas Gadjah Mada, Yogyakarta, Indonesia
}

\begin{abstract}
Monosodium glutamate (MSG) is a worldwide flavor enhancer. The excessive glutamate concentration in nerve tissue induces the death of nerve cells, known as excitotoxicity. In the orofacial region, the nerve cells' death affects pain perception such as mechanical hyperalgesia and allodynia. The aim of the present study was to examine the pain response modification and the estimated total number of trigeminal ganglion sensory neurons after sub chronic oral administration of MSG. Twenty eight male Wistar rats, aged 6-8 weeks (100-150 grams) were divided into 4 groups: Control (2 mL NaCl 0.9\%); 1 $\mathrm{mg} / \mathrm{gWB}$ MSG; $2 \mathrm{mg} / \mathrm{gWB}$ MSG; $4 \mathrm{mg} / \mathrm{gWB}$ MSG groups. Daily oral administration of MSG was given for 30 days. The control group received $\mathrm{NaCl}$ per oral for the same period. The pin prick and air puff test were performed on days 1-2, days 41-42 and days 55-56. The number of trigeminal ganglion sensory neurons were estimated by the unbiased stereology method, using the approach of numerical density and organ volume reference. The results showed that the sub chronic oral administration of MSG does not modify either the orofacial pain response or the estimated total number of trigeminal ganglion sensory neurons.
\end{abstract}

\section{Introduction}

Modern living modifies the human life style and affects human eating behavior. In the last few decades, the use of instant food is becoming dramatically increased. The instant food contains numerous additive agents, such as sweetener, food coloring and flavor enhancer. Monosodium glutamate (MSG) is a salt of Lglutamate type widely used as flavor enhancer in instant food [1]. The average daily usage of MSG in European countries ranges from $0.3-0.5 \mathrm{~g} / \mathrm{day}$. In Germany, daily intake of MSG reaches $10 \mathrm{~g} /$ day, meanwhile Asian countries people consume MSG from 1.2-1.7 g/day and reaches $4 \mathrm{~g}$ /day in high usage [2].

As an excitatory neurotransmitter, glutamate plays a key role in nerve conductivity. High glutamate concentration will transform its nature from neurotransmitter into neurotoxin and can lead to severe nerve damage [3]. Glutamate will open the $\mathrm{Ca} 2+$ ion channel followed by the rising in $\mathrm{Ca} 2+$ concentrations in the nerve cells. This circumstance begin the nerve cell death process [4].

Trigeminal ganglions consist of trigeminal nerve (N.V) sensory neurons and the satellite glial cell (SGC) complex. Trigeminal ganglion sensory neurons are divided into 2 major types based on shape, size, and density of cytoplasm: (a) Large size type A neurons show a clear cytoplasm and heavy stained nucleus. The Nissl bodies congregate at central portions of the cytoplasm and disperse at the rim of the cytoplasm. (b) Type B neurons are small to medium size, with a dark cytoplasm as a result of scattered Nissl bodies [5]. The type $A$ neurons project the myelinated $A \beta$ nerve fibers that are fast conducting fibers. The $\mathrm{B}$ type neurons project the myelinated $\mathrm{A} \delta$ and the unmyelinated, thin, $\mathrm{C}$ fibers [6,7]. Excessive glutamate concentration in the space betweentrigeminal ganglion sensory neurons and satellite glial cells induces peripheral sensitization of orofacial nerve fibers. The peripheral sensitization can affect the pain perception causing hyperalgesia (pain abnormality by noxious stimulus) and allodynia (pain abnormality by normal stimulus) [8].

According to recent study, a $150 \mathrm{mg} / \mathrm{kg}$ BW oral administration of MSG in adult men showed an increase in interstitial glutamate levels but not the increase in sensitivity of masseter muscle at 2 hours and 5 days after administration of MSG [9,10]. In another study, intravenous injection of glutamate $(10$ and $50 \mathrm{mg} / \mathrm{kg}$ BW) in Sprague-Dawley rats showed an increase in glutamate levels of the masseter muscles resulting in the decrease of mechanical stimulus threshold in afferent fibers of the masseter muscles [11].

The aims of the present study were to: (a) examine any pain response modification, and (b) estimate the number of trigeminal ganglion sensory neurons by the stereologic method in test rats after sub chronic oral administration of MSG.

*Corresponding author: amilia.ramadhani@unsoed.ac.id 


\section{Material and Methods}

\subsection{Animals and Treatment}

A total of 28 male Wistar rats, aged 6-8 weeks (100$150 \mathrm{~g}$ ) were randomly divided into 4 groups following 7 days of adaptation. These groups were: T1, T2 and T4, which received MSG per oral via oral gavage with dose 1,2 and $4 \mathrm{mg} / \mathrm{g} \mathrm{BW}$, respectively and another that is the $\mathrm{C}$ group, which received $2 \mathrm{ml}$ of $0.9 \% \mathrm{NaCl}$. The present study used $99+\%$ MSG ((PT. Sasa Inti, Probolinggo, Indonesia) with doses of $1 \mathrm{mg} / \mathrm{g} \mathrm{BW}, 2 \mathrm{mg} / \mathrm{g} \mathrm{BW}$ and 4 $\mathrm{mg} / \mathrm{g} \mathrm{BW}$ dissolved in $2 \mathrm{ml} 0.9 \% \mathrm{NaCl}$. Fresh MSG solution was prepared daily before oral administration to avoid salt crystallization.[12] All of the treatments were carried out in 30 consecutive days.

All of the present study's procedures have been reviewed and approved by Medical and Health Research Ethics Committee of Medical Faculty, Universitas Gadjah Mada, Yogyakarta, number: KE/FK/66/EC/2016.

\subsection{Test for Modification of Orofacial Pain Response}

Modifications in pain response (i.e., hyperalgesia and allodynia) were observed 3 times during the present study (on days 8\&9: pre-test; days 41\&42: posttest 1 ; and days 55\&56: posttest 2). One day before the test, all tested animals were habituated in the test room. The behavioral tests were performed in a quiet and low light room. Once in a restraining device (Fig. 1) and after a period of brief adaptation, the pin prick and the air puff stimulation were applied. All of the tests procedures were recorded and the responses were analyzed by playing the video recording in slow motion (15 frame/sec).

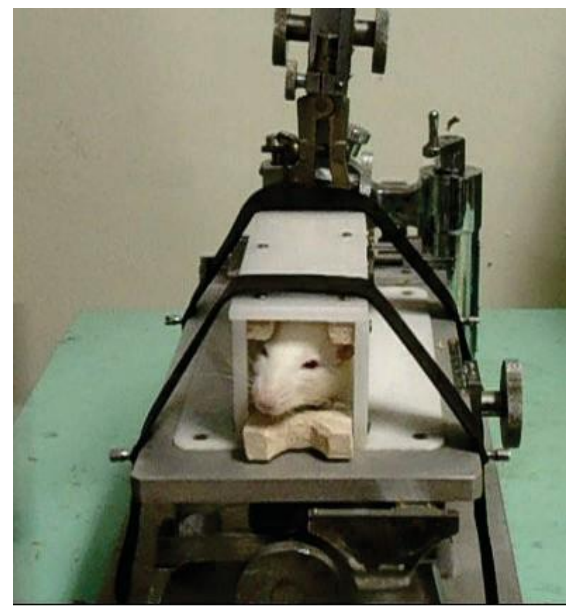

Fig. 1. Restrain device

\subsubsection{The Pin Prick Test}

The hyperalgesia response was tested using the pin prick test that applies noxious stimulus in rats' vibrissae pad and examines the responses. Using a $24 \mathrm{G}$ needle which was bent 300 and attached to the syringe, the pin prick test was applied on the right vibrissae pad twice with less than $1 \mathrm{sec}$ interval (Fig. 2) [13,14]. Scoring for the pin prick test is:

Score 0: no response

Score 1: non aversive response (detection of stimulus only)

Score 2: mild aversive response (detection of stimulus and withdrawal reaction)

Score 3: strong aversive response (detection of stimulus, withdrawal reaction and attack or escape reaction).

Score 4: prolonged aversive behavior (detection of stimulus, withdrawal reaction, attack or escape reaction and an uninterrupted series of at least 3 face swips to the stimulated area).
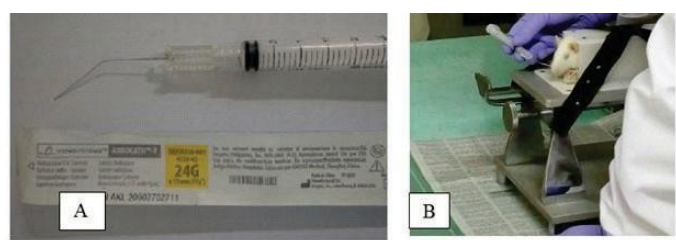

Fig 2. The pin prick test procedures. (A) Pin prick instrument, $24 \mathrm{G}$ needle, $30^{\circ}$ bend, (B) The needle apply to right vibrissae pad

\subsubsection{The Air Puff Test}

The air puff test was performed to examine the modification in allodynia mechanical threshold. The air flows from a $2 \mathrm{~cm}, 26 \mathrm{G}$ needle. The tip of the needle was placed perpendicularly $1 \mathrm{~cm}$ in front of right vibrissae pad (Fig. 3) [15]. The intensity of the air puff pressure was controlled with a calibrated manometer. The air pressure starts from $0.3 \mathrm{MPa}$ and gradually was steping down with the interval $0.025 \mathrm{MPa}$ until no withdrawal reaction appeared until no withdrawal reaction [13]. The allodynia mechanical threshold was define as the first air pressure which showed no withdrawal reaction. The thresholds were determined through the air-puff pressure at which each rat responded to the air puff in $50 \%$ of trials. The withdrawal reactions were examined by 10 trials of each air pressure (4s duration, and 10s interval) [14].

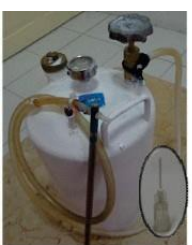

(A)

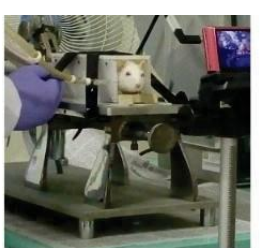

(B)

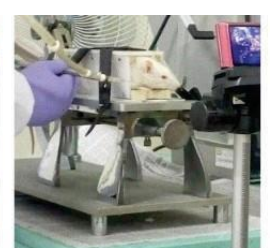

(C)
Fig 3. The air puff test procedures. (A) The air puff test apparatus, the pipe connect to the air cylinder and $26 \mathrm{G}$ needle, (B) The air flow apply to right vibrissae pad, (C) Withdrawal reaction showed after air puff test.

\subsection{Histological Procedures}

On day 61 , all subjects were euthanized using $0.5 \mathrm{cc} / \mathrm{g}$ BW Ketamine HCl (PT. Guardian Pharmatama, Jakarta, 
Indonesia) and fixed with 4\% Paraformaldehyde in Phosphate Buffer Saline through transcardiac perfusion. The trigeminal ganglion was extracted from the cranium (Fig. 4) and immersed with 4\% Paraformaldehyde for 24 hours. Then the trigeminal ganglions was dehydrated in graded concentration of alcohol, cleared in toluene solution and embedded in paraffin blocks.

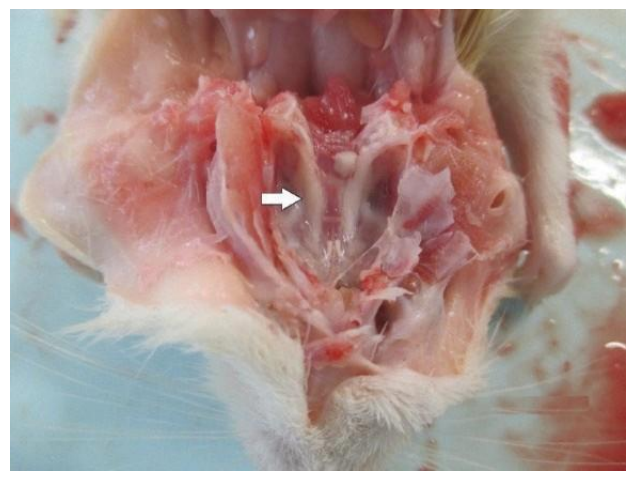

Fig 4. The site of trigeminal ganglion. The arrow head showed the position of trigeminal ganglion toward basis cranii

Pre-dehydrating and post-clearing images of trigeminal ganglion were documented to calculate the volume shrinkage. The volume shrinkage contributed as a correction factor in trigeminal ganglion volume counts. The volume shrinkage was computed with Image ${ }^{\circledR}$ program using a point grid placed over the trigeminal ganglion image (Fig. 5) and calculated by the following formula [16]:

Volume shrinkage $=1-\left(\frac{\text { post-clearing area }}{\text { pre-dehydrating area }}\right)^{1,5}$
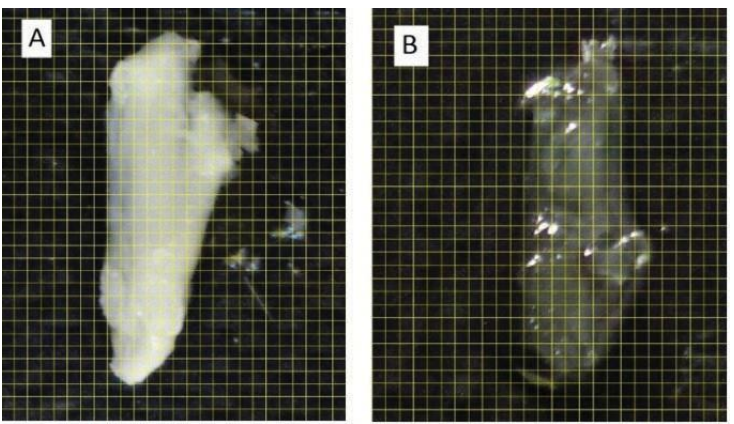

Fig 5. The volume shrinkage calculation. (A) The trigeminal ganglion image before dehydration, (B) The trigeminal ganglion image after clearing process

The trigeminal ganglion was exhaustively sectioned at $3 \mu \mathrm{m}$ in thickness, longitudinally, using Leica RM 2235 microtome (Biosystems Nussloch GmbH, Jerman). The first section of trigeminal ganglion was considered as the first slide and every section was numbered consecutively. A number between 1 and 30 was randomly chosen and this number pointed to the number of sections of every 30 sections systematically taken for stereological analyses. The specimens were mounted onto glass slides and stained with $1 \%$ toluidine blue.

\subsection{Stereological analyses}

The sections were viewed and examined under Olympus CX21FS1 (Olympus Singapore PTE, LTD) light microscope with digital camera Optilab CX-21 (Miconos Indonesia) with 40x magnification (for volume estimation) and 400x magnification (for sensory neuron density estimating). The number of trigeminal ganglion sensory neurons was estimated using physical disector probe with nucleoli as a counting unit. The estimated total number of trigeminal ganglion sensory neurons was determined by multiplying the trigeminal ganglion volume of references (Vref) and sensory neuron density $(\mathrm{Nv})$.

\subsubsection{The estimated trigeminal ganglion volume}

The trigeminal ganglion volume was estimated using the Cavalieri principle. The complete image of trigeminal ganglion section was analyzed by Image ${ }^{\circledR}$ using 21 $\mathrm{mm} \times 21 \mathrm{~mm}$ grid size. An all grid points that hit the sensory neurons of trigeminal ganglion were counted (Figure 6). The volume of the trigeminal ganglion was estimated using the following formula:

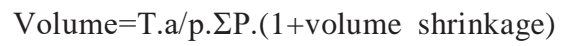

$\mathrm{T}=$ distance between sections $(\mu \mathrm{m})$

$\mathrm{a} / \mathrm{p}=$ area per $\operatorname{point}(\mu \mathrm{m} 2)$

$\Sigma \mathrm{P}=$ total points hit the sensory neuron of trigeminal ganglion.

\subsubsection{The estimated numerical density of trigeminal ganglion sensory neurons}

The estimated density of trigeminal ganglion sensory neurons was calculated using physical dissection. Systematic random sampling was always done for the first field of view for counting sensory neurons. The density of sensory neuron was calculated from the total nucleolus count in $75 \times 75 \mathrm{~mm}$ counting frame. The counting frame was comprised of two pair of lines, the dashed, inclusion line and the full drawn excluded line. This frame was superimposed the two parallel planes, the test section and the look up section, and then matched to observe the counting unit (Figure 7). The counted nucleolus is that observed in the test section but not in the look up section. The previous test section is switched to look up the section and vice versa, and continued with nucleolus count. The nucleoli which impinged with inclusion line were included in the counting frame, while the ones touched the exclusion line were excluded $[16,17]$. The numerical density of sensory neurons was calculated by using the following formula:

$$
\mathrm{Nv}=\frac{\sum \mathrm{Q}^{-}}{\text {a.h.(1+volume shrinkage })}
$$

$\mathrm{Nv}=$ the density of sensory neuron

$\Sigma$ Q- = total of counted nucleolus

$\mathrm{a} \quad=$ total area of test section $(\mu \mathrm{m})$

$\mathrm{h}=$ distance between 2 parallel plane $(\mu \mathrm{m})$ 


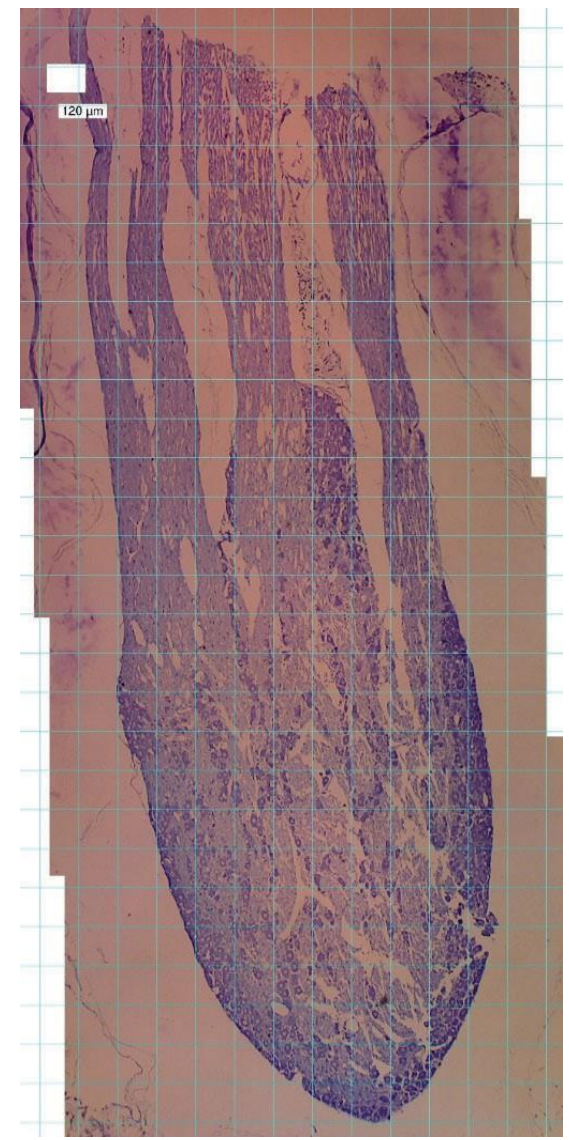

Fig 6. Estimated trigeminal ganglion volume using Cavalieri principle
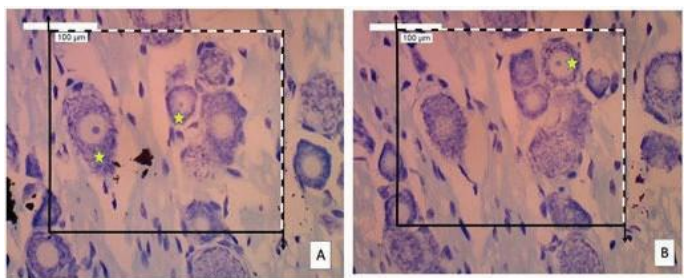

Fig 7. The counting frame. Dashes line showed inclusion line, and full drawn line showed exclusion line. A and B are paired field of view. The star mark showed counted neurons.

\subsection{Statistical analyses}

The Saphiro Wilk test was used to analize the normality of data distribution. The data that not followed normal distribution was analized using non-parametric analyses. The differences of hyperalgesia response score and allodynia mechanical threshold between groups were analyzed using the Kruskal Wallis test. The Friedman's test followed by the post-hoc Wilcoxon test were done to determine the differences of hyperalgesia responses score and allodynia mechanical threshold before and after treatment. The trigeminal ganglion volume and estimated number of sensory neurons between groups were analyzed by one-way ANOVA tests and post-hoc multiple comparisons test whenever necessary.

\section{Results}

\subsection{Hyperalgesia Response}

The increases in the pin prick score after treatment showed hyperalgesia response. The pin prick score between pretest, posttest 1 (day 31) and posttest 2 (day 45) between groups were analyzed and presented in Table 1 . There are no significant differences between all groups. ( $\mathrm{p}>0.05)$.

\subsection{Allodynia response}

The allodynia response was marked by the decrease in air pressure threshold. Table 2 showed the allodynia mechanical threshold on pretest, post-test 1 (day 42) and post-test 2 (day 46). The data were not normally distributed $(\mathrm{p}<0.05)$. Non parametric Kruskall Wallis tests showed no significant differences between pretest, post-test 1 and post-test 2 between groups. The differences of allodynia response between tests period were analyzed by the Friedman's test. The result showed significant differences in group $\mathrm{T} 1(\mathrm{p}=0.037)$ and group $\mathrm{T} 2(\mathrm{p}=0.030)$. The Wilcoxon post-hoc comparison test showed significant differences of the allodynia mechanical threshold between pre-test and post-test 2 of group $\mathrm{T} 1(\mathrm{P}=0.027)$ and between the pre-test and postest 1 of group T2 $(\mathrm{p}=0.024)$.

Table 1. Median score of pin prick test before and after treatment

\begin{tabular}{|l|l|l|l|l|l|}
\hline \multirow{2}{*}{$\begin{array}{c}\text { The pin } \\
\text { prick test } \\
\text { score }\end{array}$} & $\mathrm{C}$ & $\mathrm{T} 1$ & $\mathrm{~T} 2$ & $\mathrm{~T} 4$ & $\begin{array}{c}\text { p } \\
\text { value }^{\mathbf{c}}\end{array}$ \\
\cline { 2 - 6 } Pretest & 2.00 & 3.00 & 3.00 & 3.00 & 0.399 \\
\hline Posttest 1 & 3.00 & 3.00 & 3.00 & 2.00 & 0.655 \\
\hline Posttest 2 & 2.00 & 2.00 & 3.00 & 2.00 & 0.452 \\
\hline p value & 0.910 & 0.646 & 1.000 & 0.905 & \\
\hline C=control; & \multicolumn{5}{|c|}{$\mathrm{NaCl}=$ Natrium Cloride } \\
\hline
\end{tabular}

MSG=Monosodium Glutamate; $\mathrm{po}=$ per oral; $\mathrm{C}=2 \mathrm{ml}$ $\mathrm{NaCl}$ (po); $\mathrm{T} 1=1 \mathrm{mg} / \mathrm{g} \mathrm{BW} \mathrm{MSG}+2 \mathrm{ml} \mathrm{NaCl}$ (po); 2 2= $2 \mathrm{mg} / \mathrm{g} \mathrm{BW} \mathrm{MSG}+2 \mathrm{ml} \mathrm{NaCl}$ (po); T4= $4 \mathrm{mg} / \mathrm{g} \mathrm{BW}$ $\mathrm{MSG}+2 \mathrm{ml} \mathrm{NaCl}$ (po); $\mathrm{c}=\mathrm{p}$ values of Kruskal Wallis test; $\mathrm{d}=\mathrm{p}$ values of Friedman's test; $* \mathrm{p}<0.05$

Table 2. Mean (SD) of allodynia mechanical threshold $(\mathrm{MPa})$ before and after treatment

\begin{tabular}{|c|c|c|c|c|c|}
\hline \multirow{2}{*}{$\begin{array}{l}\text { Mechanical } \\
\text { threshold }\end{array}$} & \multicolumn{4}{|c|}{ Groups } & \multirow{2}{*}{$\begin{array}{c}\mathbf{p} \\
\text { value }^{\mathrm{c}}\end{array}$} \\
\hline & C & T1 & T2 & T4 & \\
\hline Pretest & $\begin{array}{c}0.236 \\
(0.067)\end{array}$ & $\begin{array}{c}0.268 \\
(0.019)\end{array}$ & $\begin{array}{c}0.271 \\
(0.037)\end{array}$ & $\begin{array}{c}0.250 \\
(0.069)\end{array}$ & 0.610 \\
\hline Posttest 1 & $\begin{array}{c}0.207 \\
(0.077)\end{array}$ & $\begin{array}{c}0.239 \\
(0.071)\end{array}$ & $\begin{array}{c}0.218 \\
(0.045)\end{array}$ & $\begin{array}{c}0.218 \\
(0.089)\end{array}$ & 0.632 \\
\hline Posttest 2 & $\begin{array}{c}0.221 \\
(0.065)\end{array}$ & $\begin{array}{c}0.200 \\
(0.063)\end{array}$ & $\begin{array}{c}0.232 \\
(0.028)\end{array}$ & $\begin{array}{c}0.185 \\
(0.079)\end{array}$ & 0.673 \\
\hline p value ${ }^{\mathrm{d}}$ & 0.120 & $0.037^{*}$ & $0.030^{*}$ & 0.135 & \\
\hline \multicolumn{6}{|c|}{$\mathrm{C}=$ control; $\quad \mathrm{NaCl}=$ Natrium $\quad \mathrm{Clc}$} \\
\hline
\end{tabular}


MSG $+2 \mathrm{ml} \mathrm{NaCl}(\mathrm{po}) ; \mathrm{c}=\mathrm{p}$ values of Kruskal Wallis test; $d=p$ values of Friedman's test; ${ }^{*} p<0.05$

\subsection{Trigeminal Ganglion Volume}

Table 3 shows the estimated volume of trigeminal ganglion of all groups. The one-way ANOVA test showed no significant main effect of group of trigeminal ganglion volume $(\mathrm{p}=0.860)$. The analysis for estimated precision showed precise but less effective stereological procedures in estimating the trigeminal ganglion volume $(\mathrm{CE} 2 / \mathrm{CV} 2=0.01)$. For precise and effective stereological procedures, the CE2/CV2 should be in the range 0.2 to 0.5 [18].

Table 3. Mean (SD) of trigeminal ganglion volume $\left(\mathrm{mm}^{3}\right)$ after treatment.

\begin{tabular}{|c|c|c|c|c|}
\hline Groups & $\mathbf{n}$ & $\begin{array}{l}\text { Volume } \\
\text { (SD) }\end{array}$ & CV & $\mathbf{C E}$ \\
\hline $\mathrm{C}$ & 7 & $\begin{array}{c}0.63 \\
(0.197)\end{array}$ & 0.313 & 0.026 \\
\hline T 1 & 7 & $\begin{array}{c}0.59 \\
(0.202) \\
\end{array}$ & 0.342 & 0.024 \\
\hline Т 2 & 7 & $\begin{array}{c}0.53 \\
(0.216)\end{array}$ & 0.406 & 0.024 \\
\hline $\mathrm{T} 4$ & 7 & $\begin{array}{c}0.57 \\
(0.221)\end{array}$ & 0.387 & 0.030 \\
\hline \multirow{3}{*}{$\begin{array}{l}\text { one-way } \\
\text { ANOVA }\end{array}$} & \multicolumn{2}{|c|}{$\mathrm{df}=3$} & & \\
\hline & \multicolumn{2}{|c|}{$\mathrm{p}=0.906$} & $\begin{array}{l}C V_{\text {total }} \\
=0.36\end{array}$ & $\begin{array}{c}\mathrm{CE} \text { total }= \\
0.03\end{array}$ \\
\hline & \multicolumn{2}{|c|}{$\mathrm{F}=0.184$} & $\begin{array}{l}\text { CVbiol } \\
=0.36\end{array}$ & $\begin{array}{l}\mathrm{CE}^{2} / \mathrm{CV}^{2}= \\
0.01\end{array}$ \\
\hline
\end{tabular}

$\mathrm{C}=$ control; $\quad \mathrm{NaCl}=$ Natrium $\quad$ Cloride $\quad 0.9 \%$; $\mathrm{MSG}=$ Monosodium Glutamate; $\mathrm{po}=$ per oral $\mathrm{C}=2 \mathrm{ml}$ $\mathrm{NaCl}$ (po); $\mathrm{T} 1=1 \mathrm{mg} / \mathrm{g} \mathrm{BW} \mathrm{MSG}+2 \mathrm{ml} \mathrm{NaCl}$ (ро); $\mathrm{T} 2=$ $2 \mathrm{mg} / \mathrm{g} \mathrm{BW} \mathrm{MSG}+2 \mathrm{ml} \mathrm{NaCl}$ (po); T4= $4 \mathrm{mg} / \mathrm{g} \mathrm{BW}$ $\mathrm{MSG}+2 \mathrm{ml} \mathrm{NaCl}$ (po); $\mathrm{p}=\mathrm{p}$ value of one-way ANOVA; $\mathrm{df}=$ degree of freedom, $\mathrm{CV}=$ coefficient of variation; $\mathrm{CV}_{\text {biol }}=$ coefficient of variation biological; $\mathrm{CE}=$ coefficient of error; Estimated precision : $0.2<$ $\mathrm{CE}_{\text {total }}{ }^{2} / \mathrm{CV}_{\text {total }}{ }^{2}<0.5$

\subsection{The estimated number of the sensory neuron of trigeminal ganglion}

The number of type A and B sensory neurons of trigeminal ganglion was presented in Tables 4 and 5 . One-way ANOVA tests showed no significant main effect of groups in the number of type A and B sensory neurons ( $p=0.91$ for type A sensory neuron, $p=0.754$ for type B sensory neuron). The analyses for estimated precision showed CE2/CV2 value under the estimated precision. This result means that the stereological procedures for estimating the neuron number of trigeminal ganglion was less effective.

Table 4. Mean (SD) of the number of type A trigeminal ganglion sensory neuron

\begin{tabular}{|c|c|c|c|c|c|}
\hline Groups & $\mathbf{n}$ & Nv & NA (SD) & $\mathrm{CV}$ & $\mathbf{C E}$ \\
\hline $\mathrm{C}$ & 7 & 24462.86 & $\begin{array}{l}14605.39 \\
(3958.19)\end{array}$ & 0.27 & 0.09 \\
\hline T 1 & 7 & 22907.13 & $\begin{array}{l}13095.50 \\
(3789.93)\end{array}$ & 0.29 & 0.10 \\
\hline T 2 & 7 & 34988.23 & $\begin{array}{l}13973.46 \\
(4223.31)\end{array}$ & 0.30 & 0.10 \\
\hline T 4 & 7 & 30590.72 & $\begin{array}{l}13664.78 \\
(3532.99)\end{array}$ & 0.26 & 0.10 \\
\hline \multirow{3}{*}{$\begin{array}{c}\text { one- } \\
\text { way } \\
\text { ANOVA }\end{array}$} & \multicolumn{2}{|c|}{$\mathrm{df}=3$} & \multirow{2}{*}{\multicolumn{2}{|c|}{ CVtot $=0.28$}} & \\
\hline & & $=0.91$ & & & $\begin{array}{l}\text { CE tot } \\
=0.10\end{array}$ \\
\hline & \multicolumn{2}{|c|}{$\mathrm{F}=0.184$} & \multicolumn{2}{|c|}{ CVbiol $=0.26$} & $\begin{array}{l}\mathrm{CE}^{2} / \mathrm{CV}^{2} \\
=0.12\end{array}$ \\
\hline
\end{tabular}

$\mathrm{C}=$ control; $\quad \mathrm{NaCl}=$ Natrium $\quad$ Cloride $\quad 0.9 \%$; $\mathrm{MSG}=$ Monosodium Glutamate; $\mathrm{po}=$ per oral; $\mathrm{C}=2 \mathrm{ml}$ $\mathrm{NaCl}$ (ро); $\mathrm{T} 1=1 \mathrm{mg} / \mathrm{g} \mathrm{BW} \mathrm{MSG}+2 \mathrm{ml} \mathrm{NaCl}$ (ро); $\mathrm{T} 2=$ $2 \mathrm{mg} / \mathrm{g} \mathrm{BW} \mathrm{MSG}+2 \mathrm{ml} \mathrm{NaCl}$ (po); T4= $4 \mathrm{mg} / \mathrm{g} \mathrm{BW}$ $\mathrm{MSG}+2 \mathrm{ml} \mathrm{NaCl}$ (po); $\mathrm{p}=\mathrm{p}$ value of one-way ANOVA; $\mathrm{df}=$ degree of freedom, $\mathrm{CV}=$ coefficient of variation; $\mathrm{CV}_{\mathrm{biol}}=$ coefficient of variation biological; $\mathcal{E} E_{\text {total }}={ }_{2}$ Cefficient $V_{\text {total }}<0.5$ error; Estimated precision : $0.2<$

Table 5. Mean (SD) of the number of type B trigeminal ganglion sensory neuron

\begin{tabular}{|c|c|c|c|c|c|}
\hline Groups & $\mathbf{n}$ & $\mathbf{N v}$ & $\mathbf{N}_{\mathbf{B}}$ (SD) & $\mathbf{C V}$ & $\mathbf{C E}$ \\
\hline $\mathrm{C}$ & 7 & 18966.99 & $\begin{array}{c}11227.58 \\
(2832.5)\end{array}$ & 0.25 & 0.09 \\
\hline $\mathrm{T} 1$ & 7 & 20578.35 & $\begin{array}{c}11673.57 \\
(2704.59)\end{array}$ & 0.23 & 0.08 \\
\hline T 2 & 7 & 28670.65 & $\begin{array}{c}12937.69 \\
(3571.94)\end{array}$ & 0.28 & 0.09 \\
\hline T 4 & 7 & 24801.54 & $\begin{array}{c}11906.52 \\
(2926.50)\end{array}$ & 0.25 & 0.09 \\
\hline $\begin{array}{c}\text { one- } \\
\text { way } \\
\text { ANOVA }\end{array}$ & $\mathrm{df}=3$ & \multicolumn{2}{|c|}{$\mathrm{CVtot}=0.25$} & $\begin{array}{c}\mathrm{CE} \text { tot } \\
=0.09\end{array}$ \\
\cline { 2 - 6 } & $\mathrm{p}=0.754$ & \multicolumn{2}{|c|}{$\mathrm{CVbiol}=0.24$} & $\begin{array}{c}\mathrm{CE}^{2} / \mathrm{CV}^{2} \\
=0.11\end{array}$ \\
\cline { 2 - 6 } & $\mathrm{F}=0.401$ & \multicolumn{2}{|c|}{} \\
\hline
\end{tabular}

MSG=Monosodium Glutamate; $\mathrm{po}=$ per oral; $\mathrm{C}=2 \mathrm{ml}$ $\mathrm{NaCl}$ (po); $\mathrm{T} 1=1 \mathrm{mg} / \mathrm{g} \mathrm{BW} \mathrm{MSG}+2 \mathrm{ml} \mathrm{NaCl}$ (po); $\mathrm{T} 2=$ $2 \mathrm{mg} / \mathrm{g} \mathrm{BW} \mathrm{MSG}+2 \mathrm{ml} \mathrm{NaCl}$ (po); T4= $4 \mathrm{mg} / \mathrm{g} \mathrm{BW}$ 
MSG $+2 \mathrm{ml} \mathrm{NaCl}$ (po); $\mathrm{p}=\mathrm{p}$ value of one-way ANOVA; $\mathrm{df}=$ degree of freedom, $\mathrm{F}=\mathrm{CV}=$ coefficient of variation; $\mathrm{CV}_{\text {biol }}=$ coefficient of variation biological; $\mathrm{CE}=$ coefficient of error; Estimated precision : $0.2<$ $\mathrm{CE}_{\text {total }}{ }^{2} / \mathrm{CV}_{\text {total }}{ }^{2}<0.5$

\section{Discussion}

Our study revealed that oral administration of 1,2 and 4 $\mathrm{mg} / \mathrm{g}$ BW MSG during 30 consecutive days caused no significant decrease of the allodynia mechanical threshold as well as increase of the hyperalgesia response $(p>0.05)$. Nonetheless, there was a decrease in the pain threshold value to below the normal value $(0.3$ MPa) in all groups since the pre-test. This suggested that the subjects have shown a state of allodynia since the beginning of treatment, therefore it is necessary to establish the pain threshold value as an exclusion criterion for the future study. Significant differences in pain threshold value between pre-test and post-test 2 after administration of $1 \mathrm{mg} / \mathrm{g}$ of BW MSG and between pre-test and post-test 1 after administration of $2 \mathrm{mg} / \mathrm{g}$ BW MSG indicated that changes in pain threshold values occur in dose-dependent manner. Several studies relating to administration of MSG and afferent fiber sensitization showed variant results due to different doses, administration route and experimental period [19].

The MSG dose in this study were in a range of low to high toxicity doses based on previous studies $[9,10]$. Converted dosage to $60 \mathrm{~kg}$ of equivalent human weight showed that the daily dose of MSG reach $38.4 \mathrm{~g}$ and exceeds average daily intake of European $(0.3-0.5$ g/day), German (10 g/day), and Asian (1.2 - $1.7 \mathrm{~g} /$ day $)$ [2] The real daily intake of MSG may exceed the reported data since there is usually no MSG quantity on ingredients labels of instant and processed food [20]. The afferent fibers sensitization due to different administration route of MSG showed inconsistent results. Oral administration of $75 \mathrm{mg} / \mathrm{kg} \mathrm{BW}$ and 150 $\mathrm{mg} / \mathrm{kg} \mathrm{BW}$ to 14 healthy men does not cause muscle pain and mechanical sensitization modification, 2 hours after MSG ingestion [9]. The ingestion of $150 \mathrm{mg} / \mathrm{kg}$ BW MSG for 5 consecutive day results in the increase of interstitial glutamate concentration but not in masseter muscle sensitization [10].

The parental administration of MSG showed different effect from oral administration. The sensitization of afferent fibers of masseter muscle followed by the decrease in masseter muscle mechanical threshold were shown 30 minutes after intra muscular injection of 1 M MSG [21]. Cairns et al. showed that intravenous injection of $50 \mathrm{mg} / \mathrm{kg} \mathrm{BW}$ MSG caused the increase in interstitial glutamate level of masseter muscle resulting in the sensitization of masseter muscle afferent fibers and the decrease in masseter muscle mechanical threshold [11]. Intra ganglion injection of $500 \mathrm{mM}$ glutamate affects the afferent fibers sensitization and significantly decreases mechanical threshold of masseter muscle [22].

Dietary glutamate is normally absorbed and metabolized in the small intestinal tract. The intestinal metabolism of glutamate is assumed to occur in intestinal enterocytes. Intestinal enterocyte capacity for glutamate absorption affects the circulatory glutamate level in the range of 20 $50 \mu \mathrm{M}[23,24,25]$.

Time and duration of MSG administration alter the tissue glutamate concentration. Our 30 days study presumed no increase in ganglion glutamate level near to $500 \mathrm{mM}$ since there is no evidence of hyperalgesia response and decrease of allodynia mechanical threshold. Further study is needed to examine the glutamate level in plasma and in intra ganglion to confirm the excessive glutamate level after MSG ingestion.

The inflammation of afferent fibers or adjacent tissue contributes to allodynia and hyperalgesia by the modification in transmission of chemical substances between sensory neuron and satellite glial cells of the trigeminal ganglion. The afferent fibers' inflammation induces the $\mathrm{A}-\delta$ and $\mathrm{C}$ sensory neurons of the trigeminal ganglion to release $\mathrm{P}$ substance due to NGF (Nerve Growth Factor) discharge. The P substance activates the A- $\beta$ sensory neuron and causes the modification of nonnoxious stimuli perception into a noxious (allodynia) [26]. The increase in P substance discharge of sensory neuron due to afferent fibers inflammation induces satellite glial cells to release IL $1 \quad \beta$ and causes hyperalgesia response. The release of $\mathrm{P}$ substance induces ATP discharge and locks in ATP receptors (P2Y) of satellite glial cells. The activation of P2Y receptors increases the intracellular level of $\mathrm{Ca} 2+$ and generates excitotoxicity $[6,27,28]$.

The excessive glutamate level stimulates neuronal damage and degeneration recognized as glutamate excitotoxicity [29,30]. Lagares et al. assumed that the afferent fibers damage of orofacial region caused the decrease in the volume of trigeminal ganglion and estimated number of sensory neuron of trigeminal ganglion [31].

The present study showed no significant decrease in the volume of trigeminal ganglion and estimated number neuron of trigeminal ganglion after 30 days of MSG ingestion. The glutamate level of afferent fibers nerve endings and trigeminal ganglion were regulated by satellite glial cells. The satellite glial cells play a major role to maintain the homeostasis of micro environment of trigeminal ganglion. These cells preserve the glutamate level of the extra cell and neuron-glial gap approximately 1-2 $\mu \mathrm{M}$ via EAATs. Whenever the glutamate level exceeds $2 \mu \mathrm{M}$ due to high glutamate intake or by the increase in extra cellular potassium level, the excitatory amino acid transporter (EAATs) expresses in the satellite glial cells. The damage of EAATs generates the increase in trigeminal ganglion glutamate level and causes the damage of sensory neurons and masseter muscle sensitization [3,22]. Future studies regarding to the damage of EAATs satellite glial cell by oral administration of MSG is important to reveal the mechanisms involved in trigeminal ganglion excitotoxicity.

Similar studies on other organs showed different results. Abas and El-Haleem showed vacuolization, pycnotic formation of cortex cerebral after $0.83 \mathrm{mg} / \mathrm{g}$ $\mathrm{BB}$ ingestion during 28 consecutive days [32]. Though 
there was no evidence of decline in pyramidal cells number, but the up regulation of Bax protein indicated apoptosis of pyramidal cells. Single dosage of $2 \mathrm{mg} / \mathrm{g}$ BW MSG during 10 repeated days showed evidence of glutamate-excitotoxicity in rats' hippocampus due to the up regulation of Fas-ligand, decreased of AMPK and enhanced accumulation of $\beta$-amyloid [33]. Further studies are required to reveal the important mediators of neurodegenerative changes in trigeminal ganglion sensory neurons such as the presence of AMPK or p53 protein.

\section{Conclusion}

High doses of oral administration of MSG during 30 consecutive days showed: (a) no significant modification of orofacial pain responses both hyperalgesia and allodynia, and (b) no significant differences in number of test rats' trigeminal ganglion sensory neurons in comparison between groups.

The authors acknowledge the financial support from scholarship of BPPDN (Beasiswa Pendidikan Pascasarjana Dalam Negeri) from Directorate General of Higher Education of Ministry of Research Technology and Higher Education, Indonesia (grant number 1420/E4.4/2014).

\section{References}

1. A. Ault, J Chem Educ. 81, 347-55 (2004).

2. K. Beyreuther, H.K. Biesalski, J.D. Fernstrom, P. Grimm, W.P. Hammes, U . Heinemann, O. Kempski, P. Stehle, H. Steinhart, R. Walker, Eur. J. Clin. Nutr. 61, 304-313 (2007).

3. S. Gill, O. Pulido, Glutamate Receptors in Peripheral Tissue: Excitatory Transmission Outside the CNS. Kluwer Academic, New York, (2005)

4. B.D. Larsen, I.G. Kristensen, V. Panchalingam, J.C. Laursen, N.J. Poulsen, S. M., Andersen, K. Aginsha, G. Parisa, J Recept Signal Transduct Res. 9893, 1-9 (2014).

5. A. Lagares, C. Avendaño, Brain Res. 865, 202-210 (2000).

6. M. Hanani, Brain Res Rev. 48, 457-476 (2005).

7. M.C. Rusu, F. Pop, S. Hostiuc, D. Dermengiu, A. I. Lală, D.A. Ion, V. S. Mănoiu, N. Mirancea, Ann Anat. 193, 403-411 (2011).

8. D. Purves, G.J. Augustine, D. Fitzpatrick, W.C. Hall, S. LaMantia, J.O. McNamara, et.al. Neuroscience, Sinauer Inc., USA (2004).

9. L. Baad-Hansen, B. E. Cairns, M. Ernberg, P. Svensson. Cephalalgia. 16, 1-10 (2009).

10. A. Shimada, L. Baad-Hansen, E. Castrillon, B. Ghafouri, N. Stensson, B. Gerdle, M. Ernberg, B. Cairns, P. Svensson, Nutrition. 31, 315-323 (2015).

11. B. E. Cairns, X. Dong, M. K. Mann, P. Svensson, B. J. Sessle, L. Arendt-Nielsen, et al. Pain. 132, 3341 (2007).

12. D. Prastiwi, A. Djunaidi, G. Partadiredja. Hum Exp Toxicol [Internet]. (2015).

13. B. P. Vos, A. M. Strassman, R.J. Maciewicz, Pain. 74 (1994).
14. A. Krzyzanowska, S. Pittolo, M. Cabrerizo, J. Sánchez-lópez, J. Neu Meth 201, 46-54 (2011).

15. H. J. Jeon, S. R. Han, M. K. Park, K. Y. Yang, Y. C. Bae, D. K. Ahn. Prog NeuroPsychopharmacology Biol Psychiatry 38, 149-158 (2012).

16. J. R. Nyengaard, J Am Soc Nephrol. 10, 1100-1123 (1999).

17. R. W. Boyce, K. A. Dorph-Petersen, L. Lyck, H. J. G. Gundersen. Toxicol Pathol. 38, 1011-1025 (2010).

18. J. R. Nyengaard, Personal Communication. (2014)

19. K. E. Miller, E. M. Hoffman, M. Sutharshan, R. Schechter, Pharmacol Ther 130, 283-309 (2011).

20. E. A. C. Cemaluk, E. P. Madus, O. L. Nnamdi, African J Biochem Res. 4, 225-228 (2010).

21. B. E. Cairns, G. Gambarota, P. Svensson, L. Arendt-Nielsen, C. B. Berde, Neuroscience. 109, 389-399 (2002).

22. J. C. Laursen, B. E. Cairns, X. D. Dong, U. Kumar, R. K. Somvanshi, P. Gazerani,. Neuroscience 256, 23-35 (2014).

23. P. J. Reeds, D. G. Burrin, B. Stoll, F. Jahoor, J Nutr. 978-982 (2000).

24. D. G. Burrin, B. Stoll, Am J Clin Nutr. 90 850-856 (2009).

25. M. Julio-pieper, P. J. Flor, T. G. Dinan, J. F. Cryan. Pharmacol Rev. 63, 35-58 (2011).

26. M. Takeda, S. Matsumoto. J Oral Biosci 50, 15-32 (2008).

27. M. Weick, P. S. Cherkas, W. Härtig, T. Pannicke, O. Uckermann, A. Bringmann, et al. Neuroscience. 120, 969-977 (2003).

28. M. Takeda, M. Takahashi, S. Matsumoto. Brain Behav Immun. 22, 1016-1023 (2008).

29. J.W. Olney, Science 164, 719-721 (1969).

30. W. Danysz, C. G. Parsons, I. Bresink, G. Quack. Drugs News Perspect. 8, 261-278 (1995).

31. A. Lagares, C. Avendaño, Brain Res. 865, 202-210 (2000).

32. M. A. Abass, A. R. El-Haleem, J Am Sci. 7, 264276 (2011).

33. A. E. Dief, E. S. Kamha, A. M. Baraka, A. K. Elshorbagy. Neurotoxicology 42, 76-82. (2014) 